\title{
OVLIVŇUJE CENOVÁ KOTVA V DOPRAVĚ VŠECHNY GENERACE STEJNOU MĚROU?
}

\section{IS THE INFLUENCE OF AN ANCHOR IN TRANSPORT SAME FOR EVERY GENERATION?}

\author{
Kateřina Pojkarová1,*
}

\begin{abstract}
Abstrakt Mnoho publikací bylo napsáno o působení kognitivních klamů při rozhodování, at’ už je tím klamem paradox volby, efekt volavky, haló efekt nebo klam dostupnosti. Tento článek se zaměřuje na efekt kotvy neboli vtisknutí. Lidé mají tendenci nechat se ovlivnit v podstatě jakýmkoli číslem, které uvidí pred rozhodováním o ceně zboží a jeho nákupu. Otázkou zůstává, zda se všechny generační skupiny nechají ovlivnit stejným způsobem, nebo jestli jsou různé generace různě citlivé na působení kotvy. Tato otázka byla soustředěna na oblasti rozhodování o ceně letenky, kde proběhl průzkum mezi různými generacemi. Nejen na základě analýzy rozptylu pak bylo možné konstatovat, že mladší generace jsou na vliv kotvy citlivější než ty starší.

Klíčová slova iracionální rozhodování, generace X, generace $Y$, generace Z, efekt kotvy, cena, letenky

Summary There are many articles available about cognitive biases that show why people often make irrational decisions. Cognitive biases can come in the form of decoy effects, paradoxes of choice, halo effects or availability heuristics. This paper deals with the effects anchoring or imprinting effect. People tend to be influenced by random numbers that they see before making their decisions about prices or purchases. The question is if all generations are sensitive in the same way or if there is any difference between generations when it comes to the anchoring effect. This question is answered through research on decision making in relation to plane ticket prices. Subjects were surveyed by demographics such as their generation. ANOVA was one method used which showed that younger generations were more sensitive to the anchor than the older ones.
\end{abstract}

Keywords irrational decisions, generation $X$, generation $Y$, generation $Z$, anchor effect, price, plane tickets

\section{1 ÚVOD}

Každá generace má svá specifika, v poslední době se mluví zvlášt’ o generaci Y, neboli o mileniálech, částečně proto, že v této době tvoří nejpočetnější skupinu na pracovním trhu - každý třetí pracovník patří do generace Y (Fry, 2018). Sociologové se zabývají charakterizováním jednotlivých generací a popisem

\footnotetext{
${ }^{1}$ Univerzita Pardubice, Dopravní fakulta Jana Pernera, Katedra dopravního managementu, marketingu a logistiky, Studentská 95, 53210, Pardubice, Czech Republic

*tel.: +420 466036 395, e-mail: katerina.pojkarova@upce.cz
} 
jejich typických atributů, př́padně vymezením jejich odlišností od jiných generací (Forbes, 2017, Cogin 2012, Pew Research Center, 2020).

Dá se předpokládat, že ač se v mnohém jednotlivé generace liší, mnoho budou mít společného. Všichni lidé si vytvářejí mentální zkratky, heuristiky, které jim usnadňují rozhodování. Mohou být velmi užitečné, protože bez nich by všechno trvalo př́liš dlouhou dobu, na druhou stranu mohou tyto zkratky vést k chybným rozhodnutím, což se pojí s iracionálním rozhodováním. Mezi známé heuristiky patři efekt volavky, klam dostupnosti, paradox volby a efekt kotvy. Tomu, zda jsou generace stejně náchylné k iracionalitě v rozhodování, konkrétně k vlivu kotvy, se věnuje následující text.

Cílem článku je zjistit, zda různé generace reagují na vliv kotvy stejným způsobem nebo naopak jsou odlišné generace jinak citlivé na toto kognitivní zkreslení.

\section{SOUČASNÉ POZNÁNÍ VE ZKOUMANÉ OBLASTI}

Nejen sociologové se zabývají zkoumáním charakteristik různých generačních skupin, jak je rozebráno níže.

\subsection{Generace}

Obvyklé členění, které se používá, definuje v současnosti pět generací (resp. šest, pokud počítáme i nejnovější generaci alfa narozenou po roce 2013). Nejstarší je Válečná, někdy označovaná jako Tichá generace, pro kterou je typické spoření peněz, střežení si svého soukromí, dodržování pravidel a ochota přinášet oběti. Po nich nastupuje generace zvaná Baby boomers. Je to generace zaměřená na rodinu, která dává přednosti klidu a často i izolaci. Lidé narození $v$ této generaci se neradi přizpůsobují novým věcem a jsou přesvědčeni o důležitosti tvrdé práce. Následuje generace X, v České republice označovaná jako Husákovy děti. K hodnotám této generace patří finanční zabezpečení a klidný život. Lidé z této skupiny jsou smířeni s prací přesčas, vědí, že práce je na prvním místě a že na zábavu může dojít až později. Naproti tomu Mileniálové, neboli generace Y, chodí do práce pro to, aby si mohli vydělat peníze a ty si užívat. Jsou první globalizovanou generací (Forbes, 2017). Nejsou ochotni práci obětovat všechno, chtějí si života užívat a být št'astní. Zároveň od práce očekávají, že je bude naplňovat. „Peníze jsou pro ně pouze prostředkem a nikoliv smyslem práce. $V$ dané práci potřebují vidět smysl a chtějí neustále získávat nové zkušenosti." (Sítě v hrsti, 2021) Rodina pro ně znamená omezování se, a proto ji plánují mnohem později než předchozí generace. Poslední generace, kterou má smysl zkoumat (vzhledem kvěku lidí do ní příslušejících), je generace Z. I tato generace toho chce hlavně hodně zažít, „svět vnímají skrze dotykové displeje“(Forbes, 2017). Mladí v této skupině „hodně diskutují o globálních problémech a chtějí je rešit. Všechno sdílí na sociální sítě." (Sítě v hrsti, 2021) Zaměstnanecký poměr tuto generaci neláká. Tito mladí touží změnit svět.

Ač převážně panuje shoda v tom, co je typické pro jednotlivé generace, už méně shody je v tom, které roky jsou hraniční pro přechod z jedné generace do druhé. Následující tabulka ukazuje členění generací a rozdíly $v$ př́stupech různých autorů.

Tab. 1 Rozdělení generací; zdroj: Cogin (2012), Forbes (2017), Parry a Urwin (2011), PWC Pew Research Center (2019), Schalie (2020)

\begin{tabular}{lrrrrr}
\hline Jméno generace & \multicolumn{1}{c}{ Cogin } & \multicolumn{1}{c}{ Forbes } & Parry a Urwin & PWC & \multicolumn{1}{c}{ Schalie } \\
\hline Válečná generace & $1925-1945$ & Do roku 1945 & $1925-1942$ & $1925-1945$ & $1925-1946$ \\
Baby boomers & $1946-1964$ & $1946-1967$ & $1943-1960$ & $1946-1964$ & $1946-1964$ \\
Generace X & $1965-1980$ & $1968-1982$ & $1961-1981$ & $1965-1980$ & $1965-1979$ \\
Generace Y & $1981-1995$ & $1983-1997$ & $1982-?$ & $1981-1996$ & $1980-1999$ \\
Generace Z & $1996-?$ & $1998-?$ & & $1997-2012$ & $2000-?$ \\
\hline
\end{tabular}


Vědci se zaměřují především na generaci Y, tedy na skupinou označovanou pojmem Mileniálové. Zajímají je různé věci, např. jaké je jejich očekávání ohledně vzdělání (Licite a Janmere, 2017), zda je pro ně důležitá zkušenost a závazek (Khan et al., 2021) nebo jaké jsou jejich vztahy a efektivita na pracovišti (např. Cheng et al., 2018, Alonso-Almeida a Llach, 2019, Sao a Tolani, 2018). Zkoumání proběhlo i v oblasti dopravy, například v preferencích cestovního chování. Ukazuje se, že generace Y řídí auta méně než jejich vrstevníci v předchozích generacích (Kuhnimhof et al., 2011) a častěji využívají veřejnou dopravu (Grimsrud a ElGeneidy, 2014). Řidičský průkaz získávají později a je méně pravděpodobné, že vlastní auto (Delbosc, 2017).

\subsection{Kognitivní klamy}

Pokud se mezi generacemi potvrzuje rozdílné chování a odlišné hodnoty, je možné, že budou existovat i rozdíly týkající se iracionálního chování a kognitivních klamů.

Kognitivním klamům se v 70. letech začali věnovat Daniel Kahneman a Amos Tversky (Tversky a Kahneman, 1974, Kahneman a Tversky, 1979). Ti přišli s tvrzením, že doposud používaná klasická ekonomie, pracující s člověkem racionálně jednajícím, se v praxi často nepotvrzuje. V klasické ekonomii by platilo následující tvrzení: „Ke každému z našich rozhodnutí se váže proces, který zahrnuje racionální i emocionální zvažování, přezkoumávání osobních cílů i očekávání okolí. Nakonec se berou v potaz a vyhodnocují možné alternativy. Teprve po uzavření všech těchto procesủ a po volbě vhodné možnosti, která vyhovuje jak vlastním potřebám, tak i predstavám okolí, dojde ke konečnému rozhodnutí." (Mai, 2018). Různé experimenty opakovaně potvrzují, že v praxi to tak nefunguje.

Není pravda, že lidé racionálně posoudí všechny faktory, než se rozhodnou. Spíše se potvrzuje, že „váš první dojem vám setrvává v mysli a ovlivňuje vaše další dojmy a rozhodnutí." (McRaney, 2014) To je jedno z potvrzených zkreslení, které ovlivňuje rozhodovací proces člověka. Označuje se pojmem imprinting (vtisknutí) nebo kotvení.

„Vždy, když koupíme nový produkt za nějakou cenu, stává se tato cena měř́tkem, k němuž se už vždy budeme vracet.“(Ariely, 2009) Ke vtisknutí tedy dochází tím, že si lidé spojí produkt s cenou, kterou za něj zaplatili při prvním nákupu. Zakotvit v mysli člověka však může cena ještě dříve, než k prvnímu nákupu dojde. „Kotvu si v duchu vytvář́me v okamžiku, když uvažujeme o prvním nákupu daného produktu nebo služby. Jakmile si vtiskneme do mysli první cenu, tak už s ní srovnáváme všechny další. Kotva tedy neovlivňuje jen první nákupní rozhodnutí, ale i všechna další." (Ariely, 2009)

Jako kotva dokonce může zafungovat jakékoliv číslo, které ani nemusí mít s produktem něco společného. Stačí třeba poslední dvojčíslí z rodného čísla člověka (Ariely, 2009, Pojkarová a Gottwald, 2020) nebo jakékoli jiné číslo, kterého si před nákupem zákazník všimne.

Efekt kotvy se projevuje i v jiných souvislostech, nejen při nakupování. Robert Cialdini (1975) provedl se svým týmem v 70. letech pokus, během něhož požádal studenty, aby pracovali minimálně dva roky dobrovolně jako instruktoři na táboře dvě hodiny týdně. Takovou nabídku nikdo nepřijal, ale když vzápětí přišla nabídka dohlédnout dobrovolně na dvouhodinový výlet, polovina z dotázaných $\mathrm{k}$ tomu byla ochotná. Z kontrolní skupiny, která první nabídku neměla, k tomuto dobrovolnictví nebyla svolná ani čtvrtina.

\section{ZKOUMÁNÍ VLIV KOTVY U RŮZNÝCH GENERACÍ}

Článek ověřuje, zda výše popsané vtisknutí neboli efekt kotvy, ovlivňuje stejnou měrou různé generace. Pro ověření této problematiky byl na podzim 2021 proveden průzkum, ve kterém se 388 respondentů vyjádřilo k tomu, jaká je podle nich přiměřená cena letenky do Melbourne. Jedné skupině však ještě před tím byla položena otázka, zda by byli ochotni zaplatit za letenku do Melbourne 550 Kč. Tato částka byla zvolena jako nízká kotva s očekáváním, že se dotazovaným tato cena "vtiskne" a oni poté budou i svou 
přiměřenou cenu volit nižší. Naopak druhá skupina měla v úvodní otázce nastavenou vysokou kotvu (55000 Kč za letenku na stejné trase). Podle teorie efektu kotvy bylo možné očekávat, že tato skupina bude na následující otázku (kolik je přiměřená cena za letenku) stanovovat mnohem vyšší sazby. Kontrolní skupina pak neměla žádnou otázku, která by jim vtiskla nějakou kotvu. Jejich odpovědi budou sloužit pro odhalení vlivu nízké, resp. kotvy.

Vzhledem k tomu, že není jednoznačně definováno, kterým rokem jsou ohraničeny jednotlivé generace, byly odpovědi respondentů spadajících svých rokem narození do oněch sporných let, vyřazeny z dalšího zkoumání. Pro generaci X tedy byly uvažovány pouze ročníky 1968 až 1979, pro generaci Y ročníky 1983 - 1995 a pro generaci Z 2000 - 2012. Předchozí generace se dotazování nezúčastnily v takovém počtu, aby bylo možné jejich výsledky smysluplně zkoumat.

K naplnění cíle článku budou využity základní charakteristiky souboru, jako jsou průměr a medián, a dále také analýza rozptylu. Její podstatou je posouzení významnosti vlivu některého znaku (v tomto případě př́slušnosti $\mathrm{k}$ dané generaci) na hodnotu náhodné veličiny ( $\mathrm{v}$ tomto případě na stanovenou cenu). Nulová hypotéza pro dané zkoumání je stanovena následovně: př́slušnost $\mathrm{k}$ dané generaci $(\mathrm{X}, \mathrm{Y}, \mathrm{Z})$ nemá vliv na to, k jak velkému ovlivnění cenovou kotvou dojde, resp. všechny generace jsou stejně náchylné ke zkreslení vyvolanému efektem kotvy. Alternativní hypotéza pak tvrdí, že vliv kotvy na různé generace je odlišný.

\subsection{Základní výsledky z provedeného průzkumu}

V prvním kroku bylo zkoumáno, zda kotva opravdu ovlivňuje rozhodovací proces bez ohledu věk respondenta.

Tab. 2 Základní charakteristiky kontrolní skupiny; zdroj: autor

\begin{tabular}{lrrr}
\hline & Nízká kotva & Kontrolní skupina & Vysoká kotva \\
\hline Průměr & 11497 & 16385 & 22924 \\
Minimum & 300 & 499 & 550 \\
Dolní kvantil & 4750 & 7857 & 17750 \\
Medián & 10000 & 15000 & 21000 \\
Horní kvantil & 17750 & 25000 & 30000 \\
Maximum & 30000 & 40000 & 55000 \\
\hline
\end{tabular}

Ze základních charakteristik je patrné, že průměrná přiměřená cena letenky se liší v závislosti na tom, která kotva se lidem vtiskla do povědomí. Při bližším zkoumání je vidět, že se cena pohybuje mezi 15300 Kč až 17000 Kč u kontrolní skupiny, zatímco u skupiny s nízkou kotvou je toto rozpětí zhruba od 9000 Kč po 16000 Kč, s tím, že nejnižší cenu dávali zástupci generace Z. Naopak u skupiny s vysokou kotvou se průměrná cena letenky pohybuje od 22000 Kč po 25000 Kč. Obdobné rozdíly je možné vidět i u dalších základních charakteristik. Je tedy patrné, že vtisknutá kotva má vliv na další stanovování ceny.

Tab. 3 Základní charakteristiky kontrolní skupiny; zdroj: autor

\begin{tabular}{lrrr}
\hline & generace X & generace Y & generace Z \\
\hline Průměr & 15908 & 17033 & 15379 \\
Minimum & 3000 & 900 & 499 \\
Dolní kvantil & 6250 & 10000 & 6125 \\
Medián & 13500 & 13750 & 13500 \\
Horní kvantil & 24675 & 27000 & 25000 \\
Maximum & 30000 & 35000 & 40000 \\
\hline
\end{tabular}


Tab. 4 Základní charakteristiky skupiny s nízkou kotvou; zdroj: autor

\begin{tabular}{lrrr}
\hline & generace $\mathbf{X}$ & generace $\mathbf{Y}$ & generace $\mathbf{Z}$ \\
\hline Průměr & 16327 & 12023 & 9192 \\
Minimum & 5000 & 600 & 300 \\
Dolní kvantil & 9500 & 7500 & 2125 \\
Medián & 15000 & 10000 & 8000 \\
Horní kvantil & 22750 & 18000 & 15000 \\
Maximum & 30000 & 25000 & 55000 \\
\hline
\end{tabular}

Tab. 5 Základní charakteristiky skupiny s vysokou kotvou; zdroj: autor

\begin{tabular}{lrrr}
\hline & generace $\mathbf{X}$ & generace $\mathbf{Y}$ & \multicolumn{1}{c}{ generace Z } \\
\hline Průměr & 24930 & 25136 & 22600 \\
Minimum & 15000 & 550 & 2500 \\
Dolní kvantil & 20000 & 15450 & 12000 \\
Medián & 25000 & 25000 & 20000 \\
Horní kvantil & 28500 & 32500 & 30000 \\
Maximum & 40000 & 50000 & 62000 \\
\hline
\end{tabular}

Aby další zkoumání nebylo zkresleno odlehlými hodnotami, bylo s využitím krabicového grafu určeno, zda se takové hodnoty objevují a následně byly částky 60000 Kč a 62000 Kč u generace Y (vysoká kotva) a 55000 Kč (nízká kotva u stejné generace) vypuštěny.

Na Error! Reference source not found. je ukázán rozdíl v průměrné ceně letenky, resp. mediánu ceny letenky, stanovené poté, co byla lidem vtisknuta kotva. Rozdíly mezi stanovenými hodnotami ovlivněnými kotvou jsou dobře názorné (u nízké kotvy považovali lidé za přiměřenou mnohem nižší cenu letenky než u vysoké kotvy).

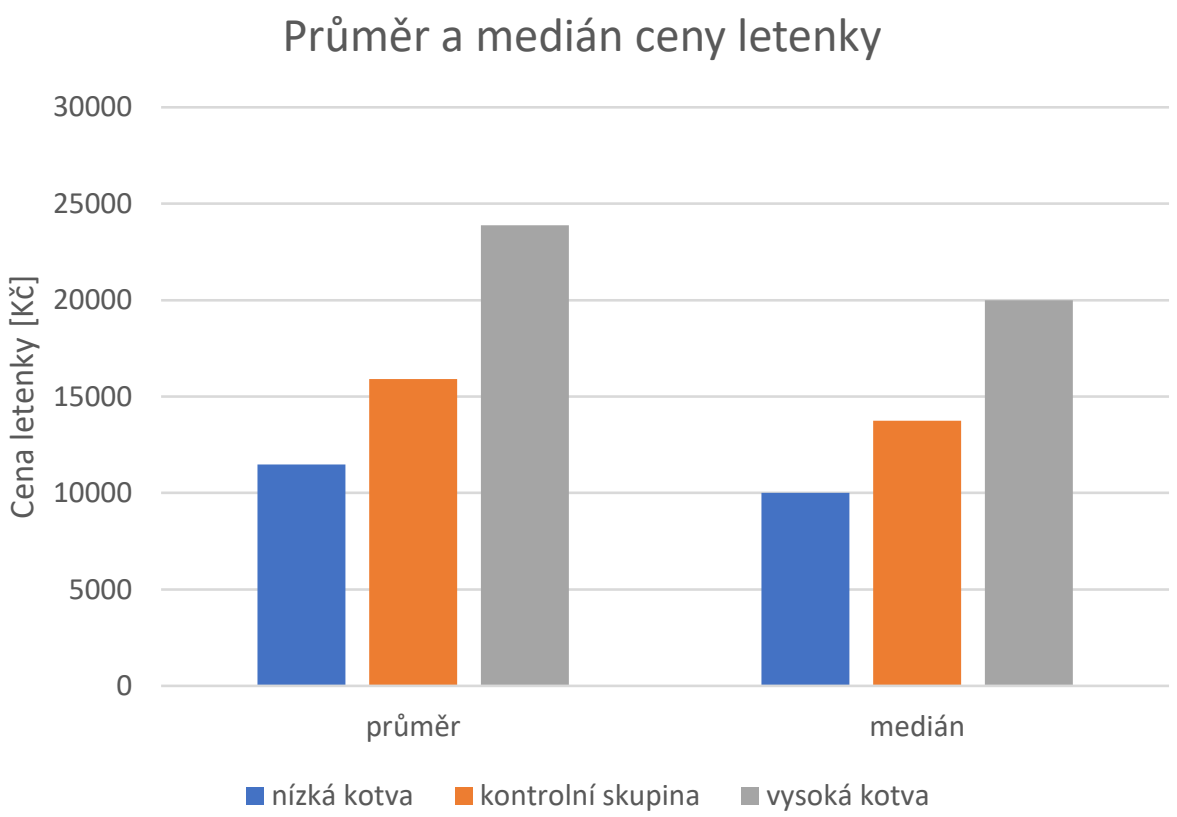

Obr. 1 Průměr a medián ceny letenky pro různé kotvy; zdroj: autor 
Vliv kotvy se potvrdil i analýzou rozptylu, která zkoumá platnost nulové hypotézy o shodnosti porovnávaných skupin (v tomto případě se porovnávala skupina cen v kontrolních dotaznících bez ohledu na generaci se skupinou v dotaznících s nízkou kotvou a skupinou ovlivněnou vysokou kotvou). Testovací statistika F vyšla 44,3, což znamená zamítnutí nulové hypotézy. P hodnota u tohoto testu vyšla menší než 0,001, a to potvrzuje velmi silně tento závěr (tedy zamítnutí nulové hypotézy o shodnosti cen). Kotva má opravdu vliv na to, jakou cenu jsou lidé následně ochotni zaplatit za daný produkt, v tomto př́padě za letenku do Melbourne. Otázkou zůstává, zda má kotva stejně velký vliv na všechny generace, nebo jestli je její vliv na různé generace odlišný.

\section{Průměr a medián ceny letenky pro různé generace}

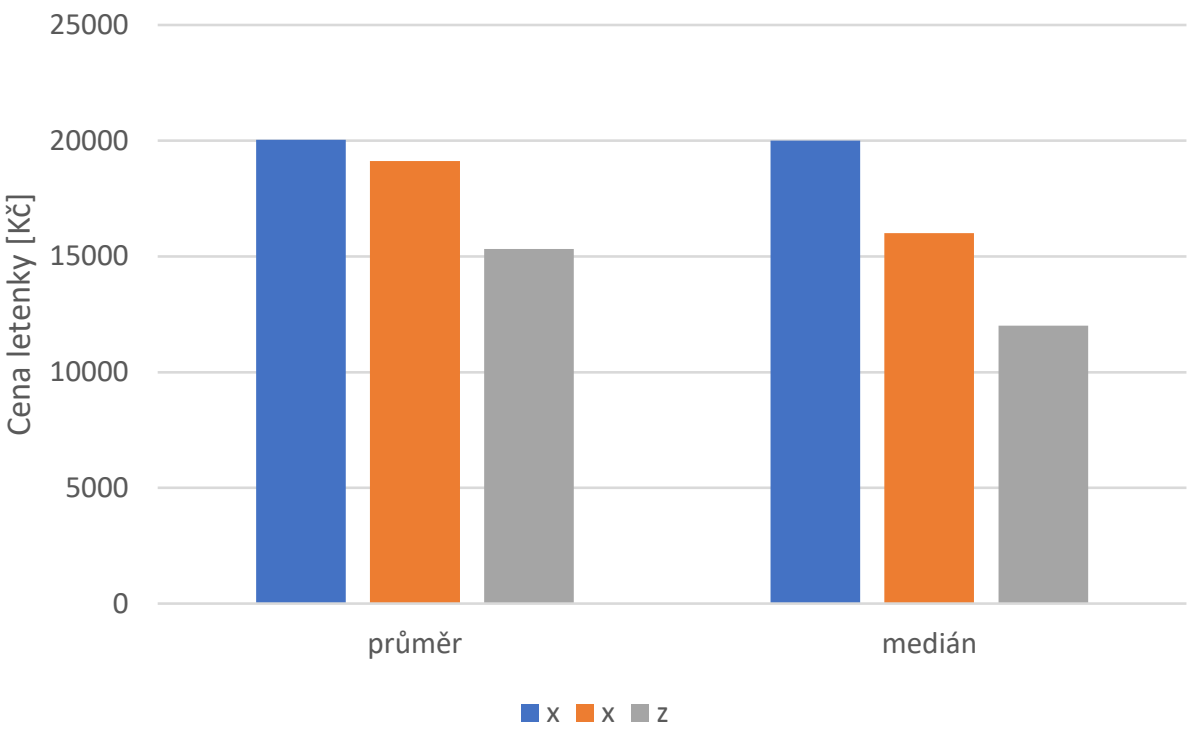

Obr. 2 Průměr a medián ceny letenky pro různé generace; zdroj: autor

Je možné porovnat ceny, které uváděli respondenti z různých generačních skupin, bez ohledu na kotvu, která jim byla vtisknuta. Testovací statistika F u analýzy rozptylu vyšla 5,02, což znamená, že odhadované ceny se liší. P hodnota u tohoto testu vyšla 0,007 , a to potvrzuje tento závěr. Je patrné, že generaci $\mathrm{X}$ stanovuje cenu vyšší (bez ohledu na kotvu) a částky stanovené jednotlivými respondenty mají zhruba o polovinu menší variabilitu, než je tomu u generací Y a Z.

\subsection{Vliv nízké kotvy na rozhodování různých generací}

V dalším kroku se zkoumání soustředilo na to, zda př́slušníci jednotlivých generací navrhují ceny za letenku obdobnou, když jsou všichni ovlivněni stejnou nízkou kotvou. 


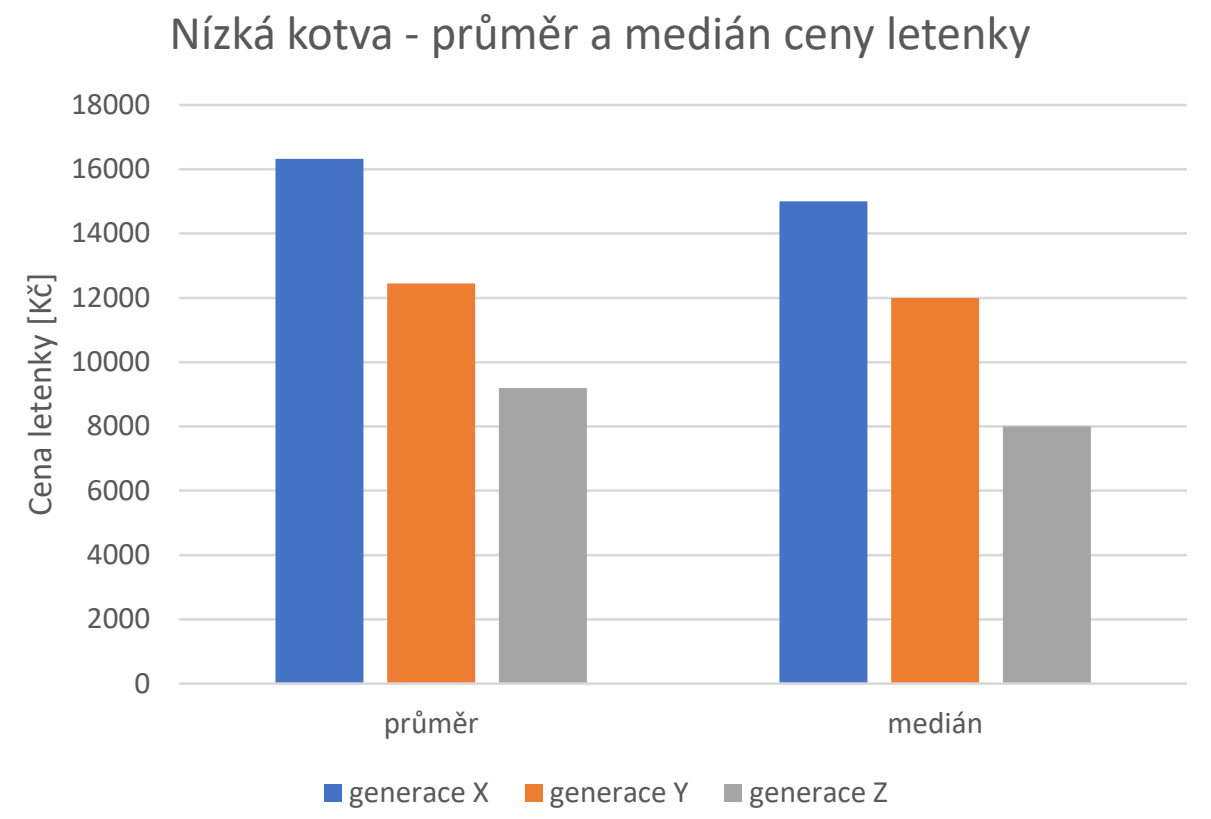

Obr. 3 Průměr a medián ceny letenky pro různé generace s vlivem nízké kotvy; zdroj: autor

Error! Reference source not found.3 znázorňuje, jak se liší cena, kterou považují jednotlivé generace ze přiměřenou, pokud jim předem byla dána nízká kotva. Pokud by věk, tedy příslušnost k uvedeným generacím, nehrál roli, pak by všechny sloupce v grafu byly zhruba stejně vysoké. Jak je patrné, generace $\mathrm{X}$ uváděla mnohem vyšší cenu než obě mladší generace. Zatímco generace X uváděla zhruba stejné ceny jako kontrolní skupina neovlivněná kotvou, generace $Y$ volila cenu zhruba o 29 \% nižší a generace Z až o 40 \% nižší ( $\mathrm{v}$ př́ípadě průměrné ceny). Rozdíly mezi cenami zvolenými jednotlivými generacemi potvrdila i analýza rozptylu, p hodnota byla menší než 0,001.

Tab. 6 Vliv nízké kotvy na průměr a medián ceny; zdroj: autor

\begin{tabular}{lrrr}
\hline & generace $\mathbf{X}$ & generace $\mathbf{Y}$ & generace Z \\
\hline Rozdíl od průměru & $+2 \%$ & $-29 \%$ & $-40 \%$ \\
Rozdíl od mediánu & $+11 \%$ & $-20 \%$ & $-40 \%$ \\
\hline
\end{tabular}

Z výše uvedeného lze tedy vyvodit s přípustnou chybou 5 \% závěr, že existuje rozdíl mezi působením nízké kotvy na rozhodování o ceně pro různé generace.

\subsection{Vliv vysoké kotvy na rozhodování různých generací}

Tak, jako byl podrobnějšímu zkoumání podroben vliv nízké kotvy, byl zkoumán i vliv kotvy vysoké. Ukázalo se, že ten je podobný u všech zkoumaných generací. Dotazovaní respondenti při použití vysoké kotvy stanovovali přiměřenou cenu za letenku do Melbourne na mnohem vyšší úrovni než v kontrolní skupině. 


\section{Vysoká kotva - průměr a medián ceny letenky}

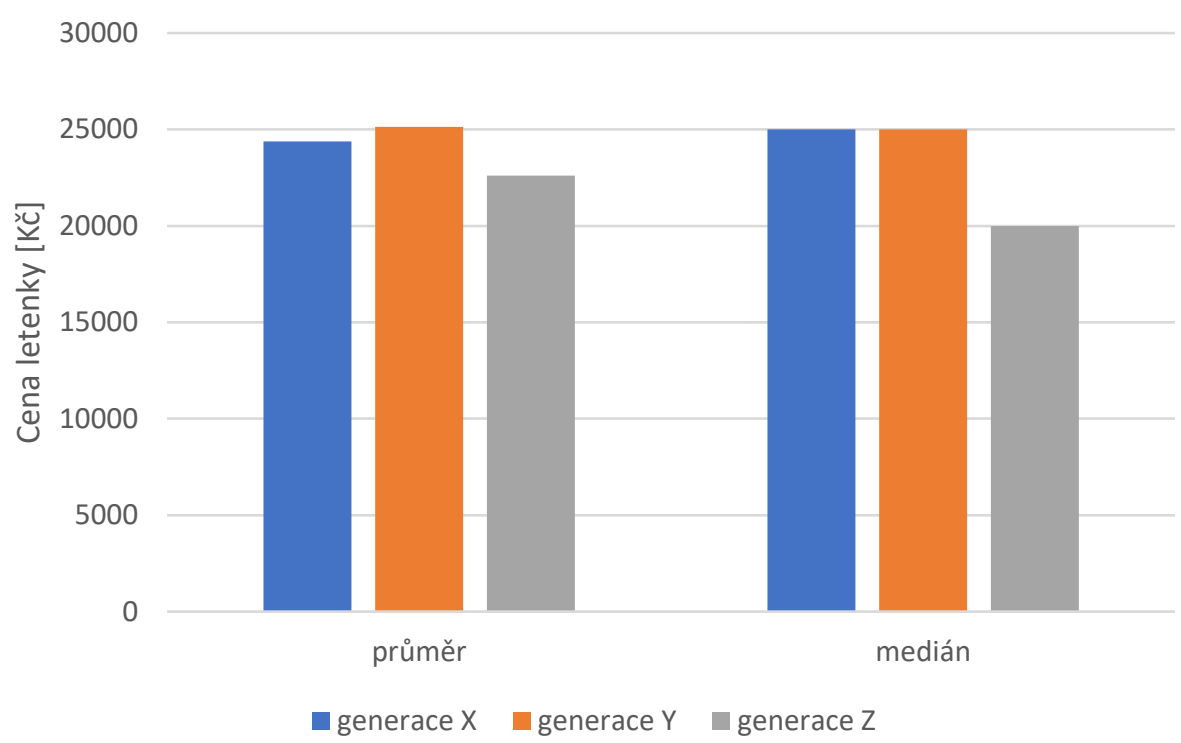

Obr. 4 Průměr a medián ceny letenky pro různé generace s vlivem vysoké kotvy; zdroj: autor

V případě vysoké kotvy se ceny stanovované jednotlivými generacemi př́liš nelišily (p hodnota analýzy rozptylu vyšla 0,51 a průměrné stanovované ceny se pohybovaly mezi 22000 Kč a 25200 Kč). Stanovené ceny byly o 53 \% vyšší než u kontrolní skupině (u generace X), pro generaci Y tento rozdíl činil 48 \% a pro generace Z 46 \%. Rozdíly v př́ípadě mediánu byly ještě větší (až $80 \%$ ).

Tab. 7 Vliv vysoké kotvy na průměr a medián ceny; zdroj: autor

\begin{tabular}{lrrr}
\hline & generace X & generace Y & generace Z \\
\hline Rozdíl od průměru & $+57 \%$ & $+48 \%$ & $+47 \%$ \\
Rozdíl od mediánu & $+85 \%$ & $+81 \%$ & $+48 \%$ \\
\hline
\end{tabular}

Při použití vysoké kotvy se tedy neprokázal rozdíl mezi cenami volenými zástupci jednotlivých generací, vliv vysoké kotvy je tedy obdobný pro všechny generační skupiny.

\subsection{Generační rozdíly u kontrolní skupiny}

Pro doplnění byly zkoumány i ceny stanovené v kontrolní skupině. Mohlo by se zdát, že mladší generace nedokážou správně odhadnout cenu letenky, protože nemají tolik zkušeností jako třeba generace X, a proto jsou náchylnější ke vlivu kotvy. Toto tvrzení se však nezdá jako pravdivé vzhledem $\mathrm{k}$ tomu, že částky zaznamenané v kontrolní skupině jsou pro všechny generace obdobné (p hodnota je 0,91 ). Bez ohledu na věk (na generaci, do které respondent spadá) je přiměřená cena pro všechny obdobná. Lidé bez ohledu na věk nebo generaci, ke které př́íslušejí, přikládají ceně letenky do Melbourne podobnou hodnotu.

\subsection{Porovnání vlivu kotvy u jednotlivých generací}

Na závěr je možné porovnat s pomocí analýzu rozptylu, zda je vliv kotvy u jednotlivých generací významný a zda je jeho vliv stejný na všechny. 
Tab. 8 P hodnota při porovnání s kontrolní skupinou; zdroj: autor

\begin{tabular}{lrrr}
\hline & generace X & generace $\mathbf{Y}$ & generace Z \\
\hline Nízká kotva & 0,88 & 0,12 & $\mathbf{0 , 0 0 4}$ \\
Vysoká kotva & 0,001 & $\mathbf{0 , 0 4}$ & $\mathbf{0 , 0 2}$ \\
Celkový vliv & $<\mathbf{0 , 0 0 1}$ & $<\mathbf{0 , 0 0 1}$ & $<\mathbf{0 , 0 0 1}$ \\
\hline
\end{tabular}

Čím nižší p hodnota u analýzy rozptylu vychází, tím silnější vliv je potvrzen. Jak ukazuje poslední tabulka, je patrné, že nízká kotva ovlivňuje rozhodovací proces méně než vysoká kotva. U generace X a Y se dokonce ani tento vliv neprokázal. Generace $\mathrm{Z}$ je na vliv jak nízké, tak vysoké kotvy mnohem citlivější.

\section{ZÁVĚR}

Průzkum provedený v oblasti rozhodování o ceně letenky do Melbourne měl za cíl odhalit, zda působení kotvy funguje u různých generací stejně, nebo zda jsou lidé různě citliví na předem vtisknuté číslo. Nulová hypotéza předpokládala, že př́slušnost $\mathrm{k}$ dané generaci $(\mathrm{X}, \mathrm{Y}, \mathrm{Z})$ nemá vliv na to, k jak velkému ovlivnění cenovou kotvou dojde, resp. že všechny generace jsou stejně náchylné ke zkreslení vyvolanému efektem kotvy. Aby bylo možné vliv kotvy důkladně prozkoumat, bylo potřeba mít i kontrolní skupinu, se kterou se pak výsledky porovnávaly. V kontrolní skupině se prokázalo, že různé věkové skupiny stanovují za přiměřenou cenu letenky zhruba stejnou hodnotu (neplatí tedy tvrzení, že např. mladší ročníky nemají představu o reálně ceně a stanovují úplně odlišné částky). Proto bylo možné zaměřit se na vliv nízké kotvy (stanovené na částku 550 Kč), resp. vysoké kotvy (55 000 Kč). Když byla lidem předložena tato částka, měli tendenci volit pak cenu letenky nižší, resp. vyšší než u kontrolní skupiny. Prokázalo se, že na nízkou kotvu není tolik citlivá generace $Y$ a už vůbec ne generace $X$. Naopak u generace $Z$ se vliv jak nízké tak vysoké kotvy potvrdil. V případě vysoké kotvy dokonce respondenti volili ceny zhruba o 50 \% vyšší než jejich vrstevníci v kontrolní skupině.

Průzkum nejen potvrdil působení kotvy na rozhodovací proces, ukázal také, že toto působení není stejné pro jednotlivé generace. Otvírá se tak oblast dalšího možného zkoumaní, která by se zaměřila nejen na potvrzení vlivu kotvy na rozhodování u jiných komodit a generací, které nebyly do tohoto zkoumání zahrnuty (například Baby Boomers), ale i na vliv dalších konfirmačních zkreslení (jako je klam dostupnosti, efekt volavky aj.)

\section{Literatura}

Alonso-Almeida, M.D.M., Llach, J. 2019. Socially responsible companies: Are they the best workplace for millennials? A cross-national analysis. Corporate Social Responsibility and Environmental Management. [online]. Dostupné z: https://doi.org/10.1002/csr.1675 [cit.: 20.10.2021].

Ariely, D. 2009. Jak drahé je zdarma. Praha: Práh

Cialdini, R. a kol. 1975, Reciprocal Concessions Procedure for Inducing Compliance: The Door-in-the-Face Technique. Journal oj Personality and Social Psychology. [online]. Dostupné z:

http://web.mit.edu/curhan/www/docs/Articles/15341 Readings/Influence Compliance/Cialdini.et.al.R eciprocal.Concessions.Procedure.1975.article.pdf 7 [cit.: 21. 10. 2021].

Cogin, J., 2012. Are generational differences in work values fact or fiction? Multi-country evidence and implications. The International Journal of Human Resource Management [online]. Dostupné z: http://www.tandfonline.com/doi/abs/10.1080/09585192.2011.610967 [cit.: 21.10.2021].

Delbosc, A. 2017. Delay or forgo? A closer look at youth driver licensing trends in the United States and Australia. Tranposrtation. [online]. Dostupné z: https://doi.org/10.1007/s11116-016-9685-7 [cit.: 20.10.2021]. 
Forbes. 2017. Práce, jídlo, peníze a vztahy. [online]. Dostupné z: http://generace.forbes.cz/tabulka/[cit.: 21. 10. 2021].

Fry, R. 2018. Pew Research Center. [Online]. Dostupné z: https://www.pewresearch.org/facttank/2018/04/11/millennials-largest-generation-us-labor-force/ [cit.: 20. 10. 2021].

Grimsrud, M., El-Geneidy, A. 2014. Transit to eternal youth: lifecycle and generational trends in Greater Montreal public transport mode share. Transportation. [online]. Dostupné z: https://doi.org/10.1007/s11116-013-9454-9 [cit.: 20. 10. 2021].

Cheng, Z., Xu, Y, Pan, Y. 2018. Dialectical relationship between millennial employee retention and wellbeing. 2nd international conference on economics and management, education, humanities and social sciences. Wuhan, 29.-30.března 2018. Wuhan, Čína: Atlantis Press, s.264-267.

Kahneman D., Tversky, A. 1979. Prospect theory - analysis of decision under risk. Econometrica. 47(2), s.263-291

Khan, Fatma, M., Kumar, V., Amoroso, S. 2021. Do experience and engagement matter to millennial consumers?. Marketing intelligence \& planning. 39 (2), 329-341.

Kuhnimhof, T., Buehler, R., Dargay, J. 2011. A New Generation: Travel Trends for young Germans and Britons. Transportation Research Record. [online]. Dostupné z: https://doi.org/10.3141/2230-07 [cit.: 20. 10. 2021].

Licite, L., Janmere, L. 2017. Millennial Student Expectations towards Higher Education in Latvia. 16th International Scientific Conference on Engineering for Rural Development. Jelgava, 24-26. Května. Jeglava, Litva: Latvia Univ Agriculture, s. 1440-1445.

Mai, J. 2018. Jakjsem šel pro mléko a vrátil se s kolem. Praha: Portál.

McRaney, D. 2014. Nejste tak chytří, jak si myslíte. Brno: BizBooks

Parry, E., Urwin, P. 2011. Generational Differences in Work Values: A Review of Theory and Evidence. IJMR. [online]. Dostupné z: https://doi.org/10.1111/i.1468-2370.2010.00285.x [cit.: 20.10. 2021].

Pew Research Center. 2019. The generations defined. [online]. Dostupné z: https://www.pewresearch.org/fact-tank/2019/01/17/where-millennials-end-and-generation-zbegins/ [cit.: 20. 10. 2021].

Pew Research Center. 2020. Millennials. [online]. Dostupné z: https://www.pewresearch.org/topic/generations-age/generations/millennials/[cit.: 20. 10. 2021].

Pojkarová, K., Gottwald, D. 2020. The irrationality of consumers choosing plane tickets. Perner's Contacts, 15(2), s. 1-12

Sao, R., Tolani, K. 2018. What Do Millennials Desire For? A Study of Expectations From Workplace. Helix. [online]. Dostupné z: http://helix.dnares.in/wp-content/uploads/2018/11/4157-4160.pdf [cit.: 20. 10. 2021].

Schalie, Barbara. 2020. Introducing Generation Z: Who Are They and How Will They Impact the Clinical Research Workplace? SOCRA. [online]. Dostupné z: https://www.socra.org/blog/introducing-generationz-who-are-they-and-how-will-they-impact-the-clinical-research-workplace/[cit.: 20. 10. 2021].

Sítě v hrsti. 2021. Kdo je Generace X, Y (miléniálové), tichá generace $Z$ a Baby boomers? [online]. Dostupné z: https://sitevhrsti.cz/generace-X-y-z-baby-boomers/ [cit.: 20.10.2021].

Tversky, A., Kahneman, D. 1974. Judgement under uncertaity - heuristics and biases. Science. 185 (4157), s. $1124-1131$ 